\title{
PENGEMBANGAN MEDIA MONOPOLI BERBASIS KONTEKSTUAL PADA MATERI JENIS-JENIS USAHA DAN KEGIATAN EKONOMI MATA PELAJARAN IPS SISWA KELAS TINGGI
}

\author{
Aslam $^{1}$, Mimin Ninawati ${ }^{2}$, Anita Noviani ${ }^{3}$ \\ ${ }^{1,2,3}$ Program Studi Pendidikan Guru Sekolah Dasar, Universitas Prof. Dr. Hamka, Indonesia \\ anitanoviani96@gmail.com
}

Naskah diterima:07 Nopember, 2020, direvisi: 26 Maret, 2021, diterbitkan: 31 Maret, 2021

\begin{abstract}
The purpose of this article is to develop contextual-based monopoly media in a social science subject and to find the feasibility of monopoly media thus that it can be used in the learning process. The research method in this research is Research and Development $(R \& D)$. The $4 D$ model stages consisted of define, design, develop, and disseminate. The number of samples used in the trial was 30 students from grade 5 SDN Mustikasari 2 kota Bekasi Jawa Barat, Indonesia. The study showed that the results of the validation of quality Monopoli media by media experts was $94 \%$ and it was categorized as very valid. Besides, the validation of material in the Monopoli that is conducted by experts depicted a high category which was $92 \%$ (very valid). Afterwards, the quality of media is tested in small groups (4 students) denoted very high percentage (84\%). In subsequent, the trial of Monopoli media through using a sample of 30 students showed a very good category which was $88 \%$ in precise. All in all, students feel happy and interested apply the contextual-based Monopoly Smart Games media and it is valuable to use as a learning media in the class especially for Grade 5 elementary school.
\end{abstract}

Keywords: Contextual learning-teaching; Instructional media; Primary school; Monopoli game

\begin{abstract}
ABSTRAK
Tujuan penelitian ini adalah untuk mengembangkan media monopoli berbasis kontekstual pada mata pelajaran Ilmu Pengetahuan Sosial (IPS) dan tujuan lainnya yaitu untuk mengetahui kelayakan media monopoli ini agar dapat digunakan di dalam proses pembelajaran. Metode penelitian dalam penelitian ini menggunakan penelitian dan pengembangan atau dikenal dengan penelitian R\&D. Tahapan model terdiri dari 4D yaitu define (pendefinisian), design (perancangan), develop (pengembangan), dan disseminate (penyebarluasan). Jumlah sampel yang digunakan dalam uji coba penelitian yaitu berjumlah 30 siswa yang berasal dari Kelas 5 SDN Mustikasari 2 kota Bekasi Jawa Barat Indonesia. Hasil penelitian menunjukkan bahwa hasil validasi oleh ahli menunjukkan presentase yang sangat tinggi yaitu mencapai $94 \%$ dan hal tersebut masuk pada kategori sangat valid. Pada validasi selanjutnya yang dilakukan oleh ahli lain menunjukkan presentase tinggi pula yaitu $92 \%$ dan hal ini berkategori sangat valid. Kemudian uji coba dilakukan pada kelompok kecil yang berjumlah 4 orang siswa menghasilkan persentase $84 \%$. Kemudian pada uji coba lain dengan menggunakan sampel 30 siswa menunjukkan presentase $88 \%$ yang berarti masuk pada kategori sangat baik. Dapat disimpulkan bahwa siswa merasa senang dan tertarik menggunakan media Monopoly Smart Games berbasis kontekstual dan media ini layak digunakan sebagai media pembelajaran untuk siswa SD terutama kelas 5.
\end{abstract}

Kata Kunci: Pembelajaran kontekstual; Media pembelajaran; Sekolah Dasar; Permainan Monopoli 


\section{Pendahuluan}

Kurikulum merupakan suatu rencana dan pengaturan yang memuat tujuan, isi, dan bahan pelajaran yang dijadikan sebagai acuan dalam menyelenggarakan pendidikan (Rusman, 2008). Muatan pelajaran yang masuk ke dalam komponen penting kurikulum salah satunya yaitu Ilmu Pengetahuan Sosial (IPS). Ilmu Pengetahuan Sosial merupakan ilmu yang mempelajari tentang kehidupan sosial yang bertujuan untuk pengajaran dan pendidikan di sekolah. Menurut Endayani (2017), Materi yang terdapat dalam IPS digunakan sebagai dasar pelaksanaan program pendidikan dan pengajaran pada sekolah. Namun siswa merasa sulit untuk memahami dan kurang antusias dikarenakan mata pelajaran IPS bersifat abstrak. Pada penelitian yang dilakukan oleh Fuad (2014), Siswa kelas V sekolah dasar ditemui terdapat kesulitan pada saat belajar IPS. Salah satu penyebab kesulitan belajar siswa pada mata pelajaran IPS yaitu guru menggunakan metode konvensional seperti ceramah. Sehingga menyebabkan siswa tidak tertarik dan tidak bosan karena proses pembelajaran yang monotan dan kurang inovatif.

Berdasarkan observasi yang dilakukan di SDN Mustikasari Kelas V Kota Bekasi, pada mata pelajaran IPS, guru menggunakan metode konvensional yang membuat siswa kurang aktif dalam mengikuti pembelajaran. Siswa merasa bahwa mata pelajaran IPS terlalu teoritis dalam menyampaikan materi sehingga membuat siswa merasa jenuh. Siswa memilih mengonrol dengan teman pada saat guru menjelaskan materi pelajaran. Hal tersebut tentunya akan mempengaruhi pemahaman materi pelajaran dan sulit menyerapkan materi yang diajarkan guru.

Pada pengelolaan pembelajaran guru harus mampu merencanakan pembelajaran dengan kreatif mulai apersepsi hingga evaluasi di akhir pembelajaran. Tujuannya dalah untuk mengajarkan serta menumbuhkan karakter positif pada siswa. Cara yang tepat yaitu dengan menggunakan permainan edukasi agar proses pembelajaran yang sebelumnya membosankan dan kondisi tegang menjadi menyenangkan (Ninawati \& Handayani, 2020). Media dalam bentuk permainan edukatif akan menumbuh karakter positif misalnya kejujuran, disiplin, tanggung jawab, serta meningkatkan hubungan sosial dan timbul motivasi dalam menangkap pembelajaran (Ninawati, 2020) Menurut Bawono (2007) dan Khobir (2009), permainan edukatif mempunyai banyak manfaat dan kelebihan yaitu mendorong siswa untuk aktif dan antusias mengikuti pelajaran.

Media pembelajaran yang tepat dalam pembelajaran salah satunya yaitu media monopoli. Media yang efektif untuk meningkatkan minat belajar siswa yaitu menggunakan media monopoli (Mardia, 2017; Siskawati, 2016; Dirgantara, 2019). Media ini bermanfaat untuk menanamkan konsep dan menemukan fakta melalui metode yang menyenangkan sehingga mengoptimalkan kompetensi individu dan kelompok. Materi yang diajarkan menggunakan media monopoli yaitu pada mata pelajaran IPS Kelas V tentang jenis-jenis usaha dan kegiatan ekonomi di Indonesia. Materi ini berguna untuk mengajarkan siswa tentang jenis usaha dan macam-macam kegiatan ekonomi yang terdapat di Indonesia. Media yang digunakan dalam mengajarkan materi ini adalah media monopoli yang dihubungkan dengan pendekatan kontekstual. Pembelajaran kontekstual mampu meningkatkan pemahaman siswa yang berguna sebagai alternative diterapkan di sekolah dasar (Ninawati, 2019). Pembelajaran kontekstual digunakan untuk mengaitkan materi yang sedang dipelajari siswa dengan dunia nyata siswa sehingga mumudahkan siswa memahami materi pelajaran. Media monopoli yang digunakan untuk memberikan pengalaman langsung siswa. Menurut Sandra (2014), pengembangan dan penggunaan media monopoli berbasis kontekstual dapat 
dijadikan sebagai media alternatif di dalam pembelajaran. Tujuan pengembangan media monopoli ini adalah untuk meningkatkan pemahaman siswa terhadap materi pelajaran IPS.

\section{Metodologi}

Model penelitian ini menggunakan model Research and Development. Tujuan penelitian dan pengembangan ini adalah untuk mengembangkan produk berupa media monopoli yang digunakan di dalam proses pembelajaran. Populasi dalam penelitian ini adalah siswa kelas V SDN Mustikasari 2 Kota Bekasi. Teknik sampling yang digunakan adalah sampling jenuh yaitu seluruh anggota populasi digunakan sebagai sampel penelitian.

Pengembangan media monopoli menggunakan model pengembangan 4D. Menurut Thiagarajan, dkk. (1974), Tahapan model 4D terdiri dari Define (pendefinisian), Design (perancangan), Develop (pengembangan), dan Disseminate (penyebarluasan). Model 4D ini dipilih disebabkan langkah pengembangannya jelas dan sesuai dengan karakteristik media yang dikembangkan.

Menurut Winarni (2018), pada Model 4D terdiri dari 4 (empat) tahapan. Tahapan pertama yaitu pendefinisian dilakukan beberapa prosedur meliputi menganalisis permasalahan dalam pengembangan media, memetakan karakteristik siswa, serta menganalisis Kompetensi Inti (KI) dan Kompetensi Dasar (KD) terhadap materi yang terdapat di dalam media. Serta menentukan indikator pencapaian pembelajaran.

Tahapan kedua Desain, tahapan kedua ini yaitu mulai menyusun prototype kemudian mengembangkan desain papan monopoli dan kartu pengumpulan gambar, menentukan pion, rumah, serta dadu. Kemudian setelah selesai masuk ke tahap produksi.

Tahapan ketiga Pengembangan, tahapan pengembangan ini setelah media monopoli selesai dikembangkan selanjutnya divalidasi oleh para ahli untuk mengukur kevalidan produk media monopoli sebelum diuji cobakan kepada siswa. Ahli yang memvalidasi media monopoli yaitu ahli media dan materi. Penilaian, saran, dan komentar ahli dijadikan sebagai dasar dalam merevisi media monopoli. Selain ahli siswa juga memberikan penilaian, saran, dan komentar untuk mengetahui kemanarikan media monopoli.

Tahapan Keempat Desiminasi, tahapan ini menganalisis data hasil uji coba dari para ahli dan respon siswa. Setelah produk diujicobakan kemudian produk media monopoli disebarluaskan untuk diimplementasikan dalam pembelajaran. Rumus untuk mengetahui kevalidan dari para ahli dan respon siswa seperti di bawah ini.

$$
P=\frac{f}{N} \times 100 \%
$$

\section{Keterangan:}

$P \quad=$ Persentase Validitas

$f \quad=$ Jumlah skor hasil pengumpulan data

$N \quad=$ Skor Maksimal

Kriteria kevalidan media monopoli ditunjukkan pada Tabel 1 di bawah ini.

Tabel 1. Presentasi Kriteria Validitas

\begin{tabular}{cc}
\hline Presentase & Kriteria \\
\hline $81 \%-100 \%$ & Sangat Valid \\
\hline $61 \%-80 \%$ & Valid \\
\hline $41 \%-60 \%$ & Kurang Valid \\
\hline $21 \%-40 \%$ & Tidak Valid \\
\hline $0 \%-20 \%$ & Sangat Tidak Valid \\
\hline
\end{tabular}


Jannah \& Julianto, 2018

\section{Hasil dan Pembahasan}

Hasil penelitian dan pengembangan media monopoli menggunakan model 4D adalah kebutuhan media pembelajaran yang menarik minat belajar siswa. Media pembelajaran yang digunakan oleh guru masih media yang bersifat sederhana misalnya papan tulis, spidol, dan buku teks seperti buku siswa. Media tersebut membuat siswa bosan dan kurang menarik. Berdasarkan analisis siswa bahwa siswa pada jenjang sekolah dasar menyukai bermain. Menurut Kurniawan (2015), siswa sekolah dasar senang bermain dan mengerjakan tugas secara berkelompok.

Media pembelajaran yang dikembangkan merupakan media yang digunakan melalui bermain. Media monopoli ini pertama, materi pelajaran dihubungkan dengan kehidupan nyata siswa melalui bermain, Kedua, proses pembelajaran dikemas dengan menyenangkan, karena bermain membuat siswa bergembira. Sebelum mengembangkan media terlebih dahulu menentukan kompetensi dasar (KD) berdasarkan Silabus Kelas V Tema 8. Selanjutnya menentukan materi yang akan dimasukkan ke dalam media monopoli. Materi yang digunakan yaitu materi jenis-jenis usaha dan kegiatan ekonomi. Analisis materi ditunjukkan pada gambar 1 di bawah ini

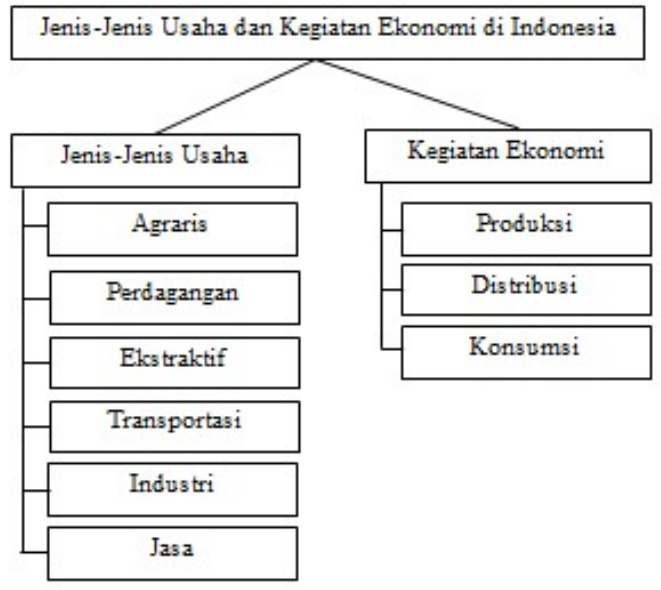

Gambar 1. Analisis Materi Jenis-Jenis Usaha Dan Kegiatan Ekonomi

Tahapan selanjutnya yaitu menganalisis tujuan pembelajaran dengan cara mengidentifikasi atau mengurutkan langkah-langkah utama agar mencapai tujuan pembelajaran. Melalui analisis tujuan pembelajaran yaitu siswa mampu menjelaskan tentang jenis-jenis usaha serta kegiatan ekonomi. Kemudian dengan bermain siswa mampu mengidentifikasi jenis usaha serta kegiatan ekonomi masyarakat Indonesia.

Tahapan desain terdiri dari pemilihan media, desain awal, dan format media. Pada tahap ini media dirancang agar sesuai dengan kebutuhan peserta didik dengan merancang dan membuat konsep media yang akan dikembangkan seperti menentukan judul, merancang bentuk papan monopoli, pengumpulan gambar, merancang konsep kartu soal, kartu materi, kartu reward dan kartu hak milik, uang dan pion, menentukan dadu dan menyusun buku petunjuk permainan. Papan monopoli yang dikembangkan dalam penelitian ini berbeda dari papan monopoli biasanya. Perbedaan yang mendasar antara papan Monopoly Smart Games dengan papan monopoli asli terletak pada bentuknyaMonopoly Smart Games berbentuk persegi 6 dan terdiri dari 6 komplek yaitu komplek A, B, C, D, E dan F. Monopoli asli 
biasanya hanya terbuat dari kertas, pada Monopoly Smart Games desain monopoli yang sudah di cetak di tempelkan pada papan kayu yang didesain menyerupai papan catur. Di dalam Monopoly Smart Games juga terdapat gambar-gambar yang berkaitan dengan materi yang diajarkan. Untuk materi jenis-jenis usaha terdapat pada komplek-komplek (A sampai F) yang berada di setiap sisi bagian monopoli. Untuk materi kegiatan ekonomi terdapat pada roda putar yang diletakkan di bagian tengah papan monopoli.Setelah menentukan bentuk papan monopoli, tahap selanjutnya yaitu mengumpulkan gambar yang berkaitan materi yang disampaikan guru dan gambar-gambar yang akan digunakan sebagai simbol-simbol pelengkap pada papan monopoli. Soal yang dimuat pada media merupakan soal pilihan ganda yang berkaitan materi pembelajaran dan disesuaikan dengan petak papan monopoli.

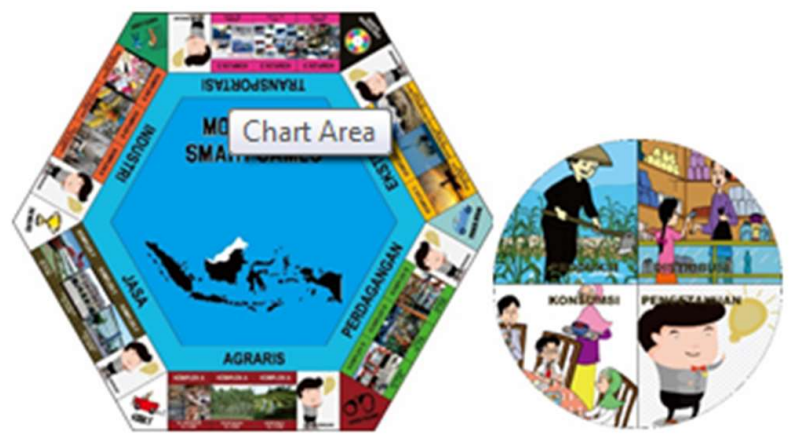

Gambar 2. Desain Awal Media Monopoli

Pada tahap Develop setelah produk media monopoli selesai dibuat, kemudian memvalidasi media monopoli. Validasi produk bertujuan untuk memvalidasi media yang dinilai oleh ahli media dan materi. Kualitas media Monopoly Smart Games ditinjau dari lima aspek, yaitu aspek fisik sebesar 97\% dengan kategori sangat valid, aspek gambar sebesar $90 \%$ masuk ke kategori sangat valid, indikator warna yaitu $90 \%$ dan berkategori sangat valid, kemudian penulisan media menunjukkan presentase $90 \%$ dan masuk kategori sangat valid, dan pada komponen penunjang media yaitu 95\% dan berkategori sangat valid. Sehingga dapat disimpulkan berdasarkan penilaian 2 (dua) ahli media yaitu rata-rata penilaian menunjukkan persentase $94 \%$ dan berkategori sangat valid.

Media monopoli selanjutnya divalidasi oleh ahli materi. Aspek yang dinilai yaitu aspek substansi/isi materi dan Bahasa. Pada aspek isi materi menunjukkan nilai presentase $94 \%$ atau kategori sangat valid. Sedangkan pada aspek Bahasa yaitu $85 \%$ yang menunjukkan kategori sangat valid. Berdasarkan uji ahli materi yang dilakukan oleh 2 (dua) ahli memperoleh rata-rata $92 \%$ dan masuk kategori sangat valid. Berdasarkan uji coba yang dilakukan menunjukkan kualitas media secara keseluruhan yaitu $84 \%$ atau masuk kategori sangat baik. Berdasarkan aspek media, penggunaan media persentase sebesar $81 \%$ dan berkategori sangat baik, aspek materi menunjukkan persentase $88 \%$ atau berkategori sangat baik, sedangkan pada aspek proses pembelajaran memperoleh persentase $87 \%$ dan masuk kategori sangat baik.

Pada tahap desiminasi menggunakan sampel sebanyak 30 siswa Kelas V SDN Mustikasari 2 Kota Bekasi. Tujuan uji coba ini adalah untuk mengetahui respon siswa setelah menggunakan media monopoli. Namun karena adanya corona virus disease (COVID-19) mengakibatkan keterbatasan dalam proses ini. Sehingga pengambilan data respon siswa dilakukan dengan cara peserta didik diminta menonton video media Monopoly Smart Games yang sudah dibuat oleh peneliti kemudian mengisi angket melalui google form yang telah disediakan. Berdasarkan uji coba media monopoli secara keseluruhan pada kelas 
VB dengan jumlah peserta didik 30 orang, mendapatkan hasil yaitu $88 \%$ dan masuk kategori sangat baik. Dilihat dari hasil peraspeknya yaitu aspek penggunaan media sebesar $88 \%$, aspek materi $88 \%$ dan aspek proses pembelajaran $88 \%$.

Produk media monopoli kemudian masuk tahap pengemasan. Tahap pengemasan yaitu melalui proses pencetakan pada seluruh komponen monopoli dan juga mencetaknya dengan jumlah yang banyakdan selanjutnya disebarluaskan. Tahap penyebaran dilakukan dengan mendistribusikan media Monopoly Smart Games untuk diberikan kepada sekolah atau guru agar bisa dimanfaatkan dalam proses pembelajaran. Tahapan 4D dalam penelitian ini sesuai dengan beberapa penelitian ( Hidayat\& Muhajir, 2015; Rosdiana, 2017; Sandra, 2014).

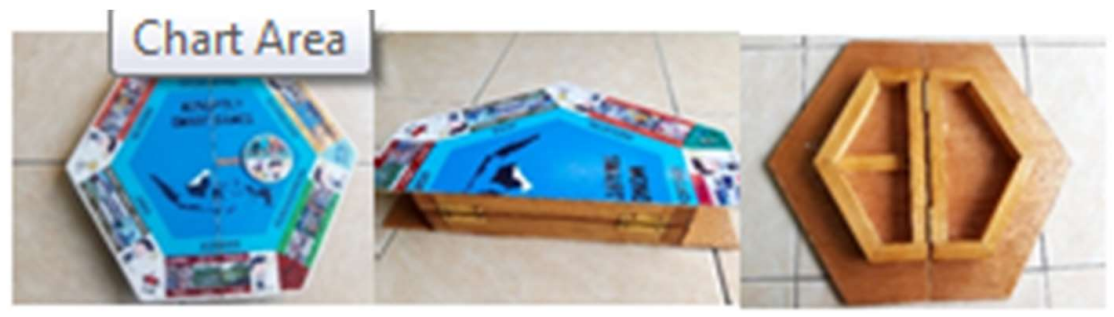

Gambar 3. Bentuk Papan Monopoli

Pada penelitian dan pengembangan ini menghasilkan media yaitu media monopoli berbasis kontekstual. Tahapan pada model 4D terdiri dari Define (pendefinisian), Design (perancangan), Develop (pengembangan), Disseminate (penyebarluasan). Hasil dari pengembangan produk ini yaitu media permainan Monopoly Smart Games yang didalamnya terdapat materi tentang jenis usaha serta kegiatan perekonomian masyarakat yang ada di Indonesia. Dalam media Monopoly Smart Games terdapat berbagai macam komponen perimainan seperi papan monopoli, kartu monopoli, uang monopoli, dadu, pion, rumah dan buku petunjuk permainan.

Validasi yang dilakukan oleh ahli media menunjukkan kategori kelayakan $94 \%$ dan masuk kategori sangat valid. Tampilan pada media Monopoly Smart Games sudah cukup jelas dan menarik. Komponen-komponen dalam Monopoly Smart Games sudah lengkap. Sedangkan pada hasil validasi oleh ahli media dengan persentase $94 \%$ atau masuk kategori sangat valid. Karena tampilan pada media Monopoly Smart Games sudah cukup jelas dan menarik. Komponen-komponen dalam Monopoly Smart Games sudah lengkap. Hal ini sesuai dengan kriteria sangat valid (Jannah \& Julianto, 2018).

Berdasarkan validasi yang dilakukan oleh ahli diperoleh persentase kalayakan materi yaitu $92 \%$ dan berkategori sangat valid. Karena materi yang terdapat dalam Monopoly Smart Games sesuai dengan kompetensi dasar serta isi media sangat lengkap sehingga mudah dipahami oleh siswa.

Uji Coba yang dilakukan pada kelompok kecil siswa, persentase yang diperoleh secara keseluruhan yaitu $84 \%$. Diketahui perolehan persentase terendah pada setiap aspeknya yaitu aspek penggunaan media dengan persentase $81 \%$ khususnya pada indikator cara penggunaan media pembelajaran. Dalam proses penelitian di uji pengembangan, peserta didik menyatakan bahwa petunjuk permainan kurang tepat terutama pada saat menjawab soal sehingga aturan permainan dirubah menjadi lebih mudah.

Pada penilaian respon siswa terhadap media monopoli melalui video, selanjutnya siswa diminta untuk mengisi angket pada google form. Pada tahap uji coba dilakukan untuk mengetahui respon peserta didik terhadap mediadengan cara menonton video media Monopoly Smart Games kemudian peserta didik diminta mengisi angket melalui google 
form. Persentase yang diperoleh dari uji coba kepada 30 siswa untuk mengetahui respon siswa terhadap media secara keseluruhan yaitu $88 \%$. Berdasarkan hasil penelitian peserta didik menyatakan bahwa media Monopoly Smart Games sangat menarik, menyenangkan dan membuat siswa paham. Sehingga media Monopoly Smart Games layak diimplementasikan pada pembelajaran. Media yang dihasilkan dalam pengembangan ini berupa media Monopoly Smart Games. Menurut Solekhah (2015), Cara untuk meningkatkan perhatian serta daya Tarik siswa yaitu melalui media monopoli.

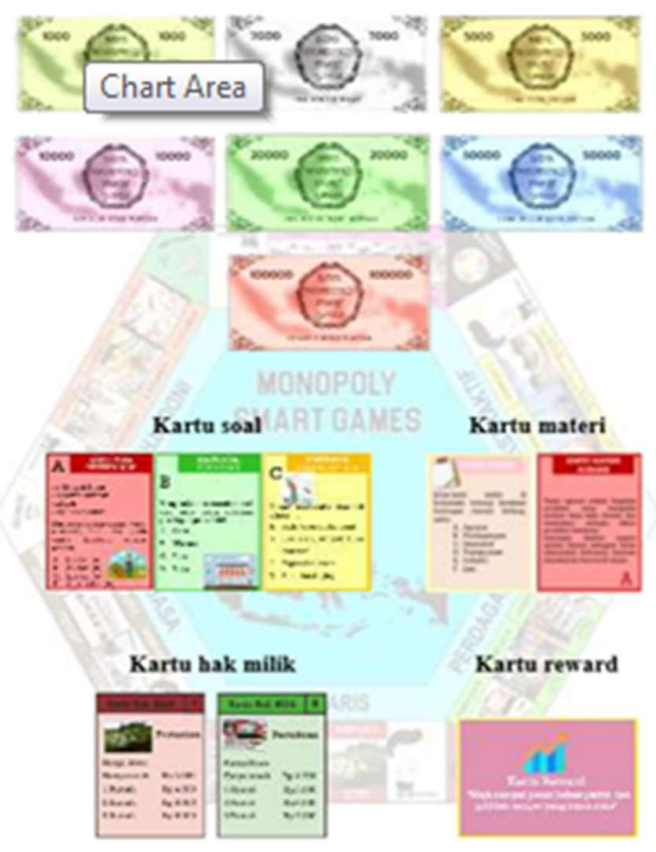

Gambar 4. Media monopoli

Gambar 3 merupakan monopoli yang dikembangkan dalam penelitian ini, media Monopoly Smart Games mempunyai kelebihan dan kekurangan. Kelebihan media Monopoly Smart Games merupakan media pembelajaran yang bisa dimainkan secara berkelompok, dengan Monopoly Smart Games siswa akan lebih mudah memahami materi yang sedang dipelajari. karena kelengkapan isinya, media mudah dipindahkan serta tidak perlu penyimpanan yang besar. Monopoly Smart Games juga memiliki kekurangan yang dapat dikembangkan dalam penelitian lainnya antara lain dalam menggunakan media Monopoly Smart Games guru wajib mendampingi untuk mengoreksi jawaban yang diberikan oleh peserta didik dan memerlukan waktu yang cukup lama dalam penggunaannya dan cukup sulit karena banyaknya aturan dalam permainan. Tahapan cara memainkan media monopoli adalah Papan monopoli berbentuk segi enam dan berisi gambar-gambar tentang jenis usaha dan kegiatan ekonomi masyarakat Indonesia. Roda putar diletakkan di tengah papan Monopoly Smart Games. Setiap pemain yang sampai pada petak-petak yang terdapat gambarnya harus menjawab kartu soal yang ada di bawah papan monopoli. Menurut Puspita, dkk (2020), Media pembelajaran pada proses pembelajaran bertujuan untuk meningkatkan efektifitas dalam penyampaian materi pembelajaran antara guru dan siswa.

\section{Kesimpulan}

Berdasarkan validasi ahli media menunjukkan presentase $94 \%$ dan berkategori sangat valid. Kemudian pada validasi ahli materi memperoleh presentase $92 \%$ dan menunjukkan kategori sangat valid. Sehingga berdasarkan uji validasi para ahli bahwa media Monopoly 
Smart Games sangat layak untuk digunakan dengan saran perbaikan yang diberikan oleh validator.

Hasil dari uji pengembangan pada siswa kelas V dilingkungan sekitar didapatkan hasil bahwa respon siswa pada media menunjukkan presentase $84 \%$ atau kategori sangat baik. Berdasarkan hasil angket yang diperoleh dari peserta didik, persentase yang paling rendah terdapat pada aspek penggunaan media, menurut peserta didik aturan dalam permainan monopoli kurang sesuai sehingga perlu dilakukan revisi dalam buku panduan Monopoly Smart Games. Untuk uji coba melalui video untuk mengetahui respon siswa pada siswa kelas V SDN Mustikasari 2 Kota Bekasi didapatkan hasil respon media sebesar $88 \%$ dan berkategori sangat baik disebabkan siswa merasa tertarik terhadap media Monopoly Smart Games, sedangkan persentase terendah diperoleh pada aspek penggunaan media terutama pada kemudahan penggunaan media, dikarenakan peserta didik hanya melihat media melalui video tanpa memainkannya sehingga indikator kemudahan penggunaan media mendapatkan persentase yang rendah.

\section{Ucapan Terima Kasih}

Ucapan terimakasih ditunjukkan pada Prodi PGSD Universitas Muhammadiyah Prof. Dr. Hamka karena telah memberikan bimbingan dan motivasi atas terselesainya penelitian dan penulisan artikel ini serta kepada pihak SDN Mustikasari 2 Kota Bekasi sebagai tempat penelitian.

\section{Daftar Pustaka}

Bawono, Yudho. (2007). Memilih Mainan Buat Si Kecil. Majalah Psikologi Plus Vol. II No. 11 Juli 2007. Semarang: PT Niko Sakti.

Dirgantara, Marvinda, R.D., Susilowati, S. M. E., Marwoto, Putut. (2019). The Use of Monopoly Media to Improve Primary Student's Critical Thinking Skills in Science Learning. Journal of Primary Education. 8 (3) (2019) : 262 - 269.

Endayani, H. (2017). Pengembangan Materi Ajar Ilmu Pengetahuan Sosial. Jurnal Program Studi Pendidikan Ilmu Pengetahuan Sosial, 1(1), 92-110. http://jurnal.uinsu.ac.id/index.php/ijtimaiyah/article/download/1158/922.

Fuada, Sofiana., (2014). Faktor Kesulitan Belajar IPS di Kelas V Sekolah Dasar Se-Gugus $V$ Kecamatan Depok Kabupaten Sleman Tahun Pelajaran 2013/2014.Thesis, unpublished. Universitas Negeri Yogyakarta.

Hidayat, A., Muhajir. (2015). Pengembangan Permainan Monopoli Sebagai Media Pembelajaran Batik Kelas V SD Siti Aminah Surabaya. Jurnal Pendidikan Seni Rupa $3(2)$.

Khobir, Abdul. (2009). Upaya Mendidik Anak dengan Permainan Edukatif. Forum Tarbiyah STAIN. 7(2).

Kurniawan, M. I. (2015). Mendidik Untuk Membentuk Karakter Siswa Sekolah Dasar: Studi Analisis Tugas Guru Dalam Mendidik Siswa Berkarakter Pribadi Yang Baik. $\begin{array}{lll}\text { PEDAGOGIA:Jurnal Pendidikan, } & 4(2),\end{array}$ https://doi.org/10.21070/pedagogia.v4i2.14.

Mardia, Ainul., Jafar, Andi Ferawati. (2017). Efektifitas Penggunaan Media Pembelajaran Monopoly Game Smart Terhadap Minat Belajar Peserta Didik. Jurnal Pendidikan Fisika. http://journal.uin-alauddin.ac.id/indeks.php/PendidikanFisika.

Ninawati, M., \& Handayani, L. (2020). Pelatihan Menumbuhkan Karakter Siswa Sekolah Dasar Tanjung Sari Melalui Permainan Edukatif Sederhana pengelolaan pembelajaran dimulai dari perencanaan, pelaksanaan, hingga pada Proses 
pembelajaran yang sudah dikelola atau direncanakan oleh guru. 09(01), 231-238.

Ninawati, Mimin., Indriani, Rina., Puspita, Ari Metalin Ika. (2019). Contextual Teaching and Learning untuk Meningkatkan Kemampuan Pemahaman Konsep Pecahan. KALAMATIKA. https://doi.org/10.22236/KALAMATIKA.vol4no1.2019pp109-116.

Puspita, A. M. I. Puspitaningsih, F. \& Diana, K. Y. (2020). Keefektifan Media Pembelajaran Powerpoint Interaktif untuk Meningkatkan Hasil Belajar Siswa Sekolah Dasar. Tanggap: Jurnal Riset dan Inovasi Pendidikan Dasar, 1(1), 49-54.

Rosdiana, M. (2017). Pengembangan Media Pembelajaran Permainan Monopoli Sains pada Siswa Kelas IV SDN Pragaan Laok I. ALPEN: Jurnal Pendidikan Dasar.

Rusman. (2008). Manajemen Kurikulum. Bandung: PT Raja Grafindo Persada.

Sandra, Lia. (2014). Pengembangan Media Pembelajaran Permainan Monopoli pada Pokok Materi Perkembangan Kerajaan Hindu-Buddha Di Indonesia Kelas XI-IPA 2 SMA Negeri 1 Driyorejo. Journal Pendidikan Sejarah 02(03).

Siskawati, Maya., Pargito,. Pujianti. (2016). Pengembangan Media Pembelajaran Monopoli untuk Meningkatkan Minat Belajar Geografi Siswa. Jurnal Studi Sosial. 04(01).

Solekhah. 2015. Pengembangan Media Monopoli Tematik Pada Tema Tempat Tinggalku Siswa Kelas IV SD N Babarsari. Jurnal Nasional 09(07).

Thiagarajan, S; Semmel, D.S; \& Semmel, M.I. 1974. Instructional Development for Training Teachers of Exceptional Children: A Sourcebook. Indiana: Indiana University.

Winarni, E. W. (2018). Teori Dan Praktik Penelitian Kuantitatif Kualitatif Penelitian Tindakan Kelas (Ptk) Research And Development (R\&D) (R. A. Kusumaningtyas (ed.); 1st ed.). PT. Cahaya Prima Sentosa. 